\title{
A Study of the Relationship between Key Factors of Academic Innovation and Faculties' Teaching Goals_-The Mediatory Role of Knowledge
}

\author{
Mehdi Mohammadi ${ }^{1}$, Rahmatullah Marzooghi ${ }^{1} \&$ Fatemeh Dehghani ${ }^{1}$ \\ ${ }^{1}$ College of Education and Psychology, Shiraz University, Iran \\ Correspondence: Mehdi Mohammadi, College of Education and Psychology, Shiraz University, Iran
}

Received: May 23, 2016

Accepted: September 27, 2016

Online Published: January 30, 2017

doi:10.5539/ies.v10n2p54

URL: http://dx.doi.org/10.5539/ies.v10n2p54

\begin{abstract}
The following research tries to study the Relationship between key factors of academic innovations and faculties' teaching goals with the mediatory role of their pedagogical, technological and content knowledge. The statistical population in this research included faculty members of Shiraz University. By simple random sampling, 127 faculty members were selected. The research instruments included of Academic Innovation Factors scale, Knowledge scale and Teaching Goals inventory. The data was analyzed, by structural equation model. Results showed Academic innovation key factors are positive predictor of various faculty members' teaching goals. Academic innovation key factors are positive predictor of faculty members' knowledge. Academic innovation key factors with the mediatory role of faculty members is positive predictor of faculty members' teaching goals.
\end{abstract}

Keywords: key factors, academic innovation, knowledge, teaching goals

\section{Introduction}

In today's world, university professors have three main duties of researching, teachings and offering services and any of these duties helps them in science production and dissemination of knowledge to the learners. (Boyer, 1990) Various factors, such as teaching strategies, work experience, academic environment, emotional intelligence, self-efficacy, self-reliance and extroversion, could impact the professors' performance. However, teaching goals plays the most significant role among all these factors. In fact, goals guide life and choices people make in their lives motivate them and in addition to the fact that they play a stimulant role in fulfilling duties and influence the information processing. (Shank, 2006) Goals impact the way thought, behavior and emotional reactions processes are organized. (Schutz, Crowder, \&White, 2001) In fact, without determining clear teaching goals, an assessment could not be carried out on the effective effort in reaching the goal, time spent for teaching and training, times when the teacher and the learner are passive in the classroom. Experience shows that setting clear teaching goals could make the teaching and learning in the classroom more effective (Angelo, 1994).

On the other hand, considering the various changes in various fields, universities should be managed and led in a way that innovation is considered as a culture and natural part of daily activities in them. In fact, academic innovation is the higher education's answer and reaction and analysis towards innovative forces and meeting these needs based on change in the future. (Christensen \& Eyring, 2011) Innovative university is a university which is capable of reacting to innovative forces, accurate analysis and answering changing needs in the future. (Christensen \& Eyring, 2011) Among the main factors in forming innovation in university, the external communication, structure, stakeholders, and regulations and rules could be referred to (Barluenga, 2010). 1) Structure: Organizational structure is the expectation of the role and the relation between them, in which individuals' duties are divided and coordinated and divided into two types of enabling structure (flexible procedures and roles and problems as learning opportunities) and preventive structure (the roles and procedures are obligatory and problems as pressure). (Hoy \& Miskel, 2008) 2) External communication: Volujevica (2012) defines external communication as the relation between organization managers and internal stakeholders of the organization and he believes that the external communications focus on the external audiences of the organization. 3) Stakeholders: Stakeholders are often identified by stakeholder groups, an individual or a group of individuals who are influential in decision makings, policies, methods, techniques, measures and goals of the organization. (Goodpastor, 1991) Also, 4) Regulations and Rules: In fact, students as the members of the 
academic society, try to choose the required time and energies needed for reaching their success, in order to ensure their success. Lessons which learning them for the students for confronting future challenges and moving in the path of integral thinking for today's society are reassuring. In this regard, it is needed that both students and faculty members have their trust in university principles which lead to integrity, mutual respect, cooperation and civil rights and accept these principles. (Arkansas University, 2010) In fact, from the knowledge management point of view, innovation is considered as a vital factor for various organizations in order to create value and save the competitive advantage in today's highly complex and dynamic environment (Ranjit, 2004).

Many of researchers such as Hill, Ball, and Schilling (2008) and McCray and Chen (2012) have shown that teachers' awareness and understandings from content knowledge and experiencing them from teaching methods can account for the extent of effectiveness as a teacher. In the field of knowledge, Mishra and Koehler (2006) refer to a technological pedagogical content knowledge (TPCK) framework and express that this framework includes three knowledge types of content knowledge, pedagogical knowledge and technological knowledge in students' teaching and learning. Content knowledge or subject knowledge, includes being professional in subjects, that requires acquiring the general content knowledges (Shulman, 1986) and specialized content knowledge. (Ball, Thames and Phelps, 2008) Pedagogical knowledge includes awareness about teaching and learning methods and strategies and the capability to design implement and evaluate the instructions which meet the students' needs. (Al-Shehri, 2012) The third type of knowledge is technological knowledge which includes the conceptual and practical understanding of information technology and the correct way to use it in various fields (Harris, Mishra, \& Koehler, 2009). Grossman (1989) and Shulman (1987) believed that content and pedagogical knowledge are considered as the foundation for effective teaching. Hence, technological knowledge of the teachers must include content and pedagogical knowledges, along with information technology, so that it could perform more effectively (Al-Shehri, 2012). Lee (2005) believes that understanding content knowledge from professors' viewpoint could help them to know how to plan programs for professional growth to lead to growth in content knowledge. Although university professors are strong in the content knowledge related to their own major, many of them have a limited knowledge about teaching theories and patters. Hence, teaching in the university is not necessarily effective. (Henson, 2003) Since digital technologies have become more similar to thought tools and they are not pedagogical tools only, technological knowledge has emerged too and this type of knowledge for the teachers include information technology along with content and pedagogical knowledge. In fact a framework of content, pedagogical and technological knowledge has emerged to explain how these three components of knowledge could combine together to teach a subject by digital technology more effectively (Mishra \& Koehler, 2006; Niess, 2005). From Angelo and Cross's (1993) point of view, pedagogical objectives are divided into six groups, including: 1) Teaching Higher-Order Thinking Skills to the Students: Lewis and Smith (1993) believe that higher-order thinking skill takes place when an individual uses the new information or the information stored in the memory and manipulates them or reorganizes the, and expands the information for accessing a goal or finding possible answer in a complex situation. 2) Teaching Basic Academic Success Skills to the Students: Basic skills could be applied to any skill which seems basic to any field of study or any set of related skills which could be reorganized as high-level skills (Allen, Altman, \& Becktold, 2000). 3) Teaching Discipline-Specific Knowledge and Skills to Students: This set of goals focus on values and specific knowledge of one major and learning terms and truth of a subject, learning the understanding to participate in a subject, learning to understand the values and aspects of a subject, are some of the goals which are categorized in this class (Angelo and Cross, 1993). 4) Teaching Liberal Arts and Academic Values: Liberal arts refers to the learning method which prepares powerful individuals to cope with complexity, variety and change and educates students with wide knowledge in wide world and students with deep understanding in areas of especial interest. (Janeksala, 2012) Academic values refer to developing understanding the value and status of humanities and natural sciences, developing commitment towards civil rights and responsibilities, awareness towards contemporary social issues, long-term learning, understanding aesthetic subjects, developing understanding in relation with sciences and technology, developing understanding towards other cultures and developing historical views related to subjects (Angelo \& Cross, 1993). 5) Teaching Work and Career Preparation to Students: This type of teaching helps students with their understanding about their own potentials and capabilities and also identifying strong and weak points and their growing needs (University of Business and Management, 2014) 6) Teaching Personal Development Skills to Students: Personal refers to accountability for self-growth and development; that is, self-development refers to developing self through self and through conscious learning processes through experiences (Honey, 2007).

Hence, according to the above-mentioned and considering the significance of academic innovation and teaching goals and also faculty members' knowledge in educational systems and universities and considering the fact that there has not been any research conducted on whether there is a significant relation between key factors of 
academic innovations and teaching goals with the mediatory role of faculty members, the following research tries to study the relation between key factors of academic innovations and teaching goals with the mediatory role of faculty members.

Academic Innovation Key factors

- Structure

- Stakeholders

- External Communication

- Regulations and Rules

Knowledge

- Content

- Pedagogical

- Technological

Teaching Goals

- Teaching Higher-Order Thinking Skills

- Basic Academic Success Skills

- Discipline-Specific Knowledge and Skills

- Liberal Arts and Academic Values

- Work and Career Preparation

- Personal Development Skills

\section{Review of Literature}

In a study under the title of The Research on University Innovative Capability Promoting Regional Innovation System, which was carried out in University of China by $\mathrm{Wu}$ (2010), research results suggested that the university affects the regional innovation system and its performance is affected by knowledge innovation, technological innovation, fostering innovation and integrated innovation. In a research carried out by Skerlavaj, Song, and Lee (2010) under the title of Organizational Learning Culture and Innovations in South Korean Firms, research results showed that organizational learning culture has a direct and strong effect on innovations and also positive moderate indirect impact on innovative culture. In a study carried out by Jing and Jin (2009) under the title of The Innovative University Library: Strategic Choice, Construction Practices and Development Ideas Shanghai University Library, have studied innovative library and innovative users in university and have come to this conclusion that to create and initiate such libraries, systematic planning and being innovative, support of users and nonstop training of them are required. In a study carried out by Kassa (2009) under the title of Effects of Different Dimensions of Social Capital on Innovative Activities in Faculty of Economics and Business Management of University of Tartu of Estonia, the results showed that social capitals are affected by innovative activities and in addition to that, various aspects of social capital have different effect on innovative activities.

In a study which was carried out by Sibuyi (2012) under the title of Effective Teachers Pedagogical Content Knowledge in Teaching Quadratic Functions in Mathematics, the research studied the content and pedagogical knowledges by two mathematics teachers from the State of Mpumalanga, when they were teaching the quadratic functions in $11^{\text {th }}$ grade. Results suggested that both teachers retained the proper content knowledge, while they had some limitations in teaching strategies and the knowledge related to misconceptions and presuppositions of learners towards quadratic functions and lacked the knowledge. Many researchers such as Al-Shehri (2012), McCray and Chen (2012) and Hill et al. (2008) in studying these three knowledge came to this conclusion that teachers' understanding from content knowledge of mathematics and their specialization in teaching methods and teachers' capabilities in applying technology in their teachings have a rather great impact on teachers' effectiveness.

In a study carried out by Medallon (2013) under the title of Faculty Performance as a Function of teaching Goals and Organizational Commitment which was conducted on 70 faculty members in order to determine the relations of professors' performance through using variables of professors' teaching goals, organizational commitment and personality traits, they came to this conclusion that accessing the teaching goals in humanities and academic values have a significant relation with specialization. 
In a study conducted by Johnson (1997) under the title of Faculty Teaching Goals at Senior Research Universities among six disciplines of accounting, computers, economics, English, math, mechanical engineering and psychology, the research results showed that there is a significant difference observed among the factors means in eight disciplines. Comparing the initial teaching role among the eight disciplines also, showed a significant difference in the rate of choosing any of the six roles by the professors. In a study which was conducted by Angelo and Cross (1993) under the title of Teaching Goals of Faculty Members in Four-Year Local Colleges, the research results indicated that teaching priorities of faculty members is related to the discipline, more than any other factors. Faculty members of humanities, English and Social Sciences, had dedicated their primary teaching goal to higher-order thinking skills. Teaching facts and principles was the primary teaching goal among sciences and mathematics faculty members. In business and medicine, the faculty members dedicated their primary teaching goal to work and career preparation of students and in arts, they focused on personal development of students. In a study carried out byLiebert and Bayer (1975), they studied the faculty members' goals in teaching undergraduates students. Research results showed those faculty members' teaching goals in colleges and four-year universities are focused on the intellectual growth of students mostly, and less weight is given to personal and ethical developments.

The following research tries to reach the following objectives:

1) Identifying the relation between academic innovation key factors, knowledge and faculty members' teaching goals

2) Identifying the power academic innovation key factors in predicting faculty members' teaching goals

3) Identifying the power academic innovation key factors in predicting faculty members' knowledge

4) Identifying the power academic innovation key factors with the mediatory role of knowledge in predicting faculty members' teaching goals

\section{Method}

Considering the fact that this research studies the relation between academic innovation key factors and teaching goals with the mediatory role of content, pedagogical and technical knowledge of faculty members, the reach method in this study is descriptive and of correlative type.

The statistical population in this research included all 200 faculty members if Shiraz Farhangiyan University and among whom, 127 individuals were selected for the research through using Krejcie and Morgan Table and using simple random sampling. The data collection tool in this research included three scales of: A) Innovative University Key Factors: To evaluate the academic innovation key factors researcher made Innovative University Key Factors scale was used. This scale included two parts: a) Demographics b) Innovative University Key Factors. This scale is based on four aspects of structure, stakeholders, external communications and regulations and rules. It includes 40 items of 5-item Likert scale. B) Faculty Members' Knowledge: To evaluate faculty members' knowledge, the Knowledge scale (Al-Shehri, 2012) was used. This scale is based on three aspects of content knowledge, pedagogical knowledge and technological knowledge (Al-Shehri, 2012) and includes 28 items. However, one of the items was omitted due to incompatibility with the culture of society and it is graded based on 5-item Likert scale. C) Faculty Members' Teaching Goals: To evaluate the faculty members' teaching goals the Teaching Goal scale (Angelo and Cross, 1993) was used. This questionnaire is based on six aspects of higher-order thinking skills, discipline-specific knowledge and skills, work and career preparation, personal development skills, liberal arts and academic values, and basic academic success skills (Angelo and Cross, 1993) which includes 52 items and graded based on 5-item Likert scale.

Item analysis was used for validity of scales. The validity of the Innovative University Key Factors scale was 0.93, Knowledge scale item was 0.75 and Faculty Teaching Goals scale for higher-order thinking skills (0.77-0.90), basic academic success skills(0.92-0.93), discipline-specific knowledge and skills (0.91-0.92), liberal arts and academic values (0.92-0.95), work and career preparation (0.90-0.96) and personal development skills (0.89-0.95) confirmed the instruments validity. For reliability of this scale, Cronbach's alpha was used. The Cronbach's alpha of the Innovative University Key Factors scale was 0.91 , Knowledge scale item was 0.75 and Faculty Teaching Goals scale for higher-order thinking skills $(0.80)$, basic academic success skills $(0.87)$, discipline-specific knowledge and skills (0.88), liberal arts and academic values (0.90), work and career preparation (0.91) and personal development skills (0.94) confirmed the instruments reliability. For analyzing the data, structural equating model was used.

\section{Results}

1) Is academic innovation key factors significant predictor of faculty members' teaching goals? 
Acceding to Figure 1, results suggest that academic innovation key factors are significant predictors of various teaching goals of higher-order thinking skills, basic academic success skills, discipline-specific knowledge, liberal arts and academic values, work and career preparation and personal development. Among various teaching goals, academic innovation key factors are predictor of work and career preparation, basic academic success skills, personal development and discipline-specific knowledge, higher-order thinking skills and liberal arts and academic values, respectively.

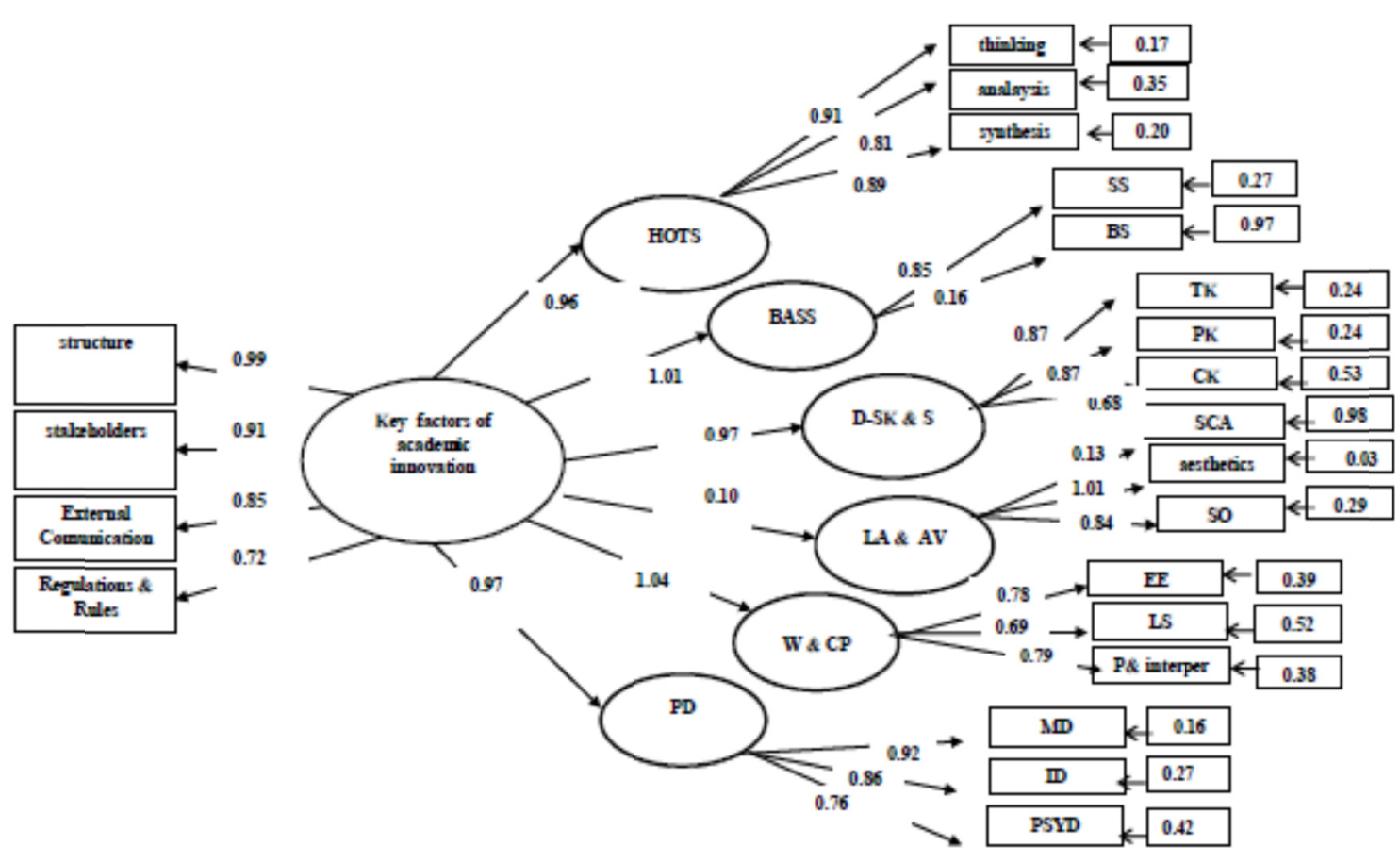

Figure 1. The ultimate model of the relation between academic innovation key factors and teaching goals

2) Is academic innovation key factors significant predictor of faculty members' knowledge?

Acceding to Figure 2, results suggest that academic innovation key factors are significant predictor of faculty members' knowledge.



Figure 2. The ultimate model of the relation between academic innovation key factors and knowledge 
3) Is the academic innovation key factors significant predictor of faculty members' teaching goals with the mediatory role of knowledge?

According to Figure 3, Results showed that academic innovation key factors both directly and indirectly is significant predictor of the various faculties' teaching goals of higher-order thinking skills, basic academic success skills, discipline-specific knowledge, liberal arts and academic values, work and career preparation and personal development. Among various teaching goals, academic innovation key factors with the mediatory role of knowledge are predictor of discipline-specific knowledge, work and career preparation, liberal arts and academic values, basic academic success skills, personal development and, higher-order thinking skills, respectively.

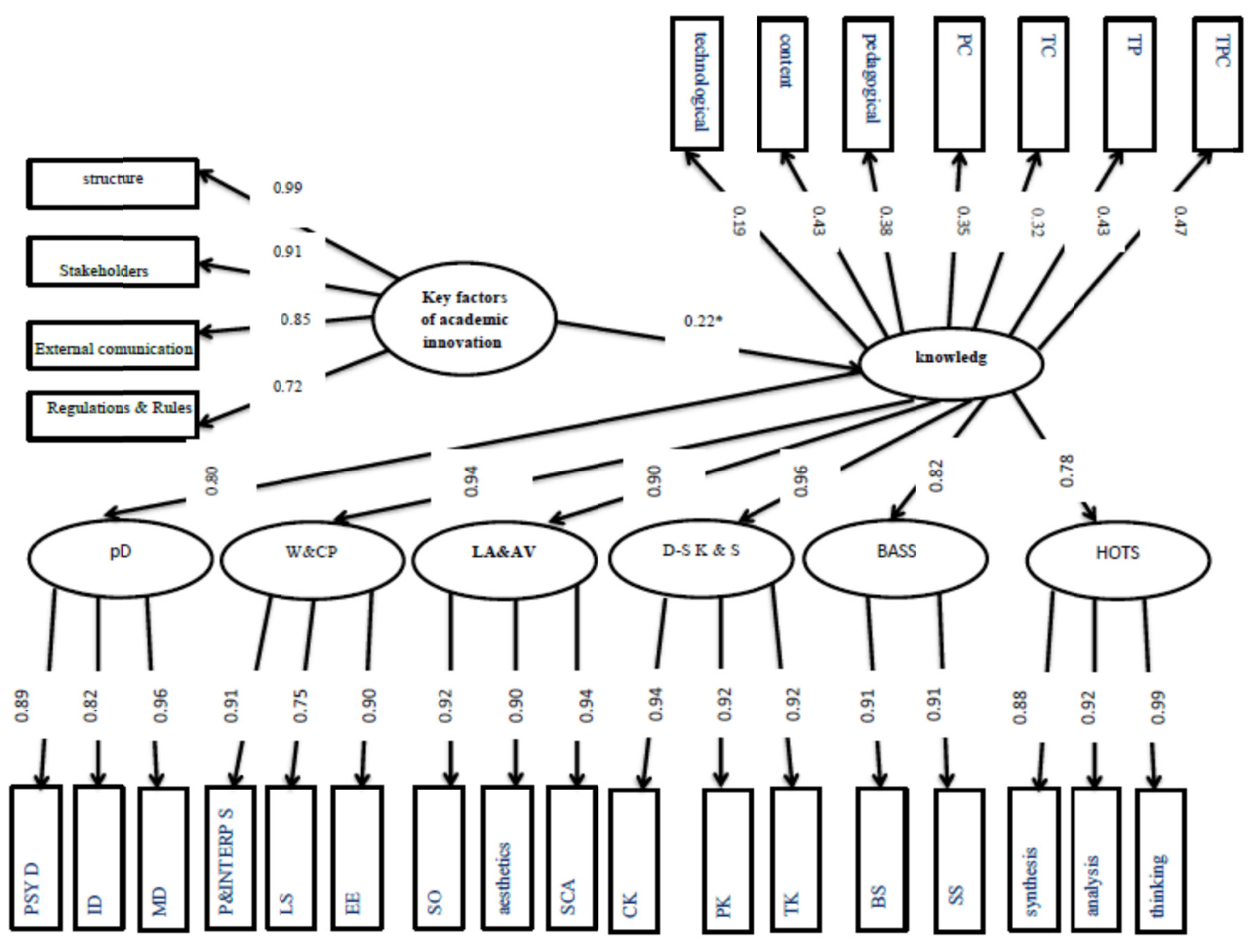

Figure 3. The ultimate model of the relation between academic innovation key factors and teaching goals with the mediatory role of faculty members' knowledge

HOTS $=$ Higher-order Thinking skillS, BASS $=$ Basic Academic Success Skills, LA\&AV $=$ Liberal Arts and Academic value, $\mathrm{W} \& \mathrm{CP}=$ Work and Career Preparation, $\mathrm{PD}=$ Personal Development, $\mathrm{Pc}=$ Pedagogical content, $\mathrm{TC}=$ Technological content, $\mathrm{TP}=$ Technological Pedagogy, $\mathrm{TPC}=$ Technological Pedagogical Content, $\mathrm{SS}=$ Study skills, $\mathrm{BS}=$ Basic skills, $\mathrm{TK}=$ Theoretical knowledge, $\mathrm{PK}=$ practical knowledge, $\mathrm{CK}=$ career knowledge, $\mathrm{SCA}=$ Socio-cultural awareness, $\mathrm{SO}=$ Scientific openness, $\mathrm{EE}=$ Employee engagement, $\mathrm{LS}=$ Leadership skills, P\&INTERP S= Personal and interpersonal skills, $\mathrm{MD}=$ Moral development, I D= Intellectual development, PSY $\mathrm{D}=$ Psychophysical development.

\section{Discussion and Conclusion}

According to the results from structural equation, academic innovation key factors are positive and significant predictors of knowledge, from faculty members' viewpoint. In fact, the main core of university is its stakeholders and by realization of the situation for change and innovation, they can provide play their main role in improving the university by creation, development and upgrade of their knowledge. In fact, one of the challenges of 
university authorities is to provide a proper environment for growth and training the mind of the members of a knowledge-oriented university. Hence, managing the knowledge is considered as the main skill of managers in universities. In fact, the knowledge capitals which are sometimes known as intellectual capital and intangible assets include intellectual, knowledge and information materials and the organization could use them for creating knowledge. (Kong, 2007) Hence, it could be claimed that by the formation of innovative universities, along with changes, a space could be created for growth and training of minds of a university members (stakeholders) and forming new knowledge in them. All educational organizations need novel ideas for their survival. Innovation can be considered as organizational change for meeting the external environment or dominance on it. In fact, from the viewpoints of Shiraz Farhangiyan University faculty members, innovative university could provide the context for spreading various types of knowledge and most importantly, the pedagogical knowledge and pedagogical and technological knowledge in its own faculty members, as the main stakeholders of the university. In innovative university, faculty members could benefit from various teaching methods, processes and techniques, novel teaching and learning strategies, novel ideas in teaching and learning, merging various novel technologies in teaching and learning, innovative methods for globalizing teaching and learning methods and processes.

However, in studying the mediatory role of faculty members' knowledge, according to the results from structural equation, academic innovation key factors with the mediatory role of are positive and significant predictors of knowledge, from faculty members' viewpoint. According to the results from structural equation, from Shiraz Farhangiyan University faculty members' viewpoint, the factor of structure had the highest factor loading, comparing to the other factors of academic innovation. It might be due to the fact that in the desirable state, the aspect of structure is considered more; and the structure of Farhangiyan University might be in a way that faculty members and students could reach the determined roles goals for teaching. And in the variable of teaching goals, work and career preparation aspect has the highest prediction power, which might be due to the significance of work and career preparation of students-teachers in Farhangiyan University, from Shiraz Farhangiyan University faculty members' viewpoint. Hence, in explaining the final result of this analysis, it could be generally claimed that academic innovation key factors with the mediatory role of knowledge, impact the process and rate of realization teaching goals determined by Shiraz Farhangiyan University faculty members.

Results suggest that from the faculty members' viewpoints, by providing the situation for innovation in university, their pedagogical knowledge (knowledge of teaching processes and methods) and content pedagogical technological knowledge (compiling knowledge of teaching subject, knowledge of methods, pedagogical techniques and knowledge of technological tools appropriate for teaching) grows and develops. And this helps them to achieve their teaching goals. In fact, innovative organization pattern triumphantly needs an innovation-oriented, dynamic and flexible structure along with creative and believing managers in all management aspects.

\section{References}

Allen, J., Altman, C., \& Becktold, L. (2000). The State of Basic Skills Instruction in California Community Colleges. Ad Hoc Committee.

Al-shehri, K. A. (2012). The influence of mathematics teachers' knowledge in technology, pedagogy and content (tpack) on their teaching effectiveness in Saudi public schools.

Angelo, T. (1994). Teaching Goals, Assessment, Academic Freedom and Higher Learning. A Journal of Essays on Teaching Excellence, Toward the Best in the Academy, 5(7).

Angelo, T. A., \& Cross, K. P. (1993). Classroom assessment techniques: A handbook for college teachers (2nd ed.). San Francisco: Jossey-Bass.

Angelo, T. A., \& Cross, K. P. (1993). Teaching Goals Inventory, Classroom Assessment techniques (pp. 13-23). San Francisco: Jossey-Bass.

Arkansas's University. (2010). Office of the Associate vice Chancell or/Dean of Students A Faculty and Staff Guide to: Dealing with Disruptive Behavior. Retrieved from http://vcfa.uark.edu/Documents/FayPol_FacStaff_4160.pdf

Ball, D. L., Thames, M. H., \& Phelps, G. (2008). Content knowledge for teaching: What makes it special? Journal of Teacher Education, 59(5), 389-407. https://doi.org/10.1177/0022487108324554

Barluenga, M. (2010). Becoming an Innovative University. 1st Training Module: Strategic Implementation of University-Industry Cooperation Oran. 
Boyer, E. L. (1990). Scholarship Reconsidered: Priorities of The Professoriate, The Carnegie Foundation, For The Advancement of Teaching.

Christensen, C. M., \& Eyring, H. J. (2011). The Innovative University: Changing the DNA of Higher Education from the Inside out (Jossey-Bass Higher and Adult Education Series). Jossey-Bass Publishers; 1 edition.

Christensen, C. M., \& Eyring, H. J. (2011). The Innovative University: Changing the DNA of higher education from the inside out. San Francisco, CA: Jossey-Bass.

Goodpaster, K., (1991). Business Ethics and Stakeholders Analysis. Business Ethics Quarterly, 1(1), 53-73.

Grossman, P. L. (1989). A study in contrast: Sources of pedagogical content knowledge for secondary English. Journal of Teacher Education, 40(5), 24-31. https://doi.org/10.1177/002248718904000504

Hanson, J. (2003); Encouraging Lecturers to Engage with New Technologies in Learning and Teaching in a Vocational University: The Role of Recognition Reward. Journal of Higher Education Management and Policy, 15, 3. https://doi.org/10.1787/hemp-v15-art28-en

Harris, J., Mishra, P., \& Koehler, M. J. (2009). Teachers' Technological Pedagogical Content Knowledge and learning activity types: Curriculum-based technology integration reframed. Journal of Research on Technology in Education, 41(4), 393-416. https://doi.org/10.1080/15391523.2009.10782536

Hill, H. C., Ball, D. L., \& Schilling, S. G. (2008). Unpacking Pedagogical Content Knowledge: Conceptualizing and measuring teachers' topic-specific knowledge of students. Journal for Research in Mathematics Education, 39(4), 372-400.

Honey, P. (2007). Continuing Personal Development. Published By Peter Honey Publication Limited.

Hoy, K. W., \& Miskel, G. C. (2008). Educational Administration: Theory, Research, and Practice. McGraw Hill, Hill Companise Inc, 1221. Retrieved from http://vcfa.uark.edu/Documents/FayPol_FacStaff_4160.pdf

Janeksala, G. M. (2012). The Value of a Liberal Arts Education. Academic Exchange Quarterly, 16(4).

Jing, G., \& Jin, C. (2009). The innovative university library: strategic choice, construction practices and development ideas. Shanghai Jiao Tong University Library, Shanghai, PR China. Library Management, 30, (4/5), 295-308.

Johnson, D. L. (1997). Faculty Teaching Goals at Senior Research Universities (Dissertation submitted for the degree of Doctor of Philosophy in Educational Administration, Blacksburg, Virginia).

Kassa, A. (2009). Effects of Different Dimensions of Social Capital on Innovative Activity: Evidence from

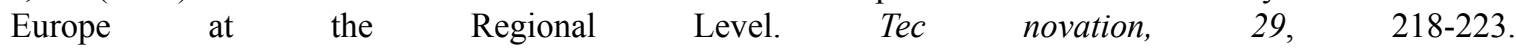
https://doi.org/10.1016/j.technovation.2008.01.003

Kong, E. (2007). The strategic importance of intellectual capital in the non-profit sector. Journal of Intellectual capital, 8(4), 721-731. https://doi.org/10.1108/14691930710830864

Lee, E. (2005). Conceptualizing pedagogical content knowledge from the perspective of experienced secondary science teachers (Ph. D. dissertation of the University of Texas at Austin).

Lewis, A., \& Smith, D. (1993). Defining higher order thinking. Theory into Practice, 32(3), 131.

Liebert, R. J., \& Bayer, A. E. (1975). Goals in teaching undergraduates: Professional reproductions and client centeredness. The American Sociologist, 10, 195-205.

McCray, J. S., \& Chen, J. Q. (2012). Pedagogical content knowledge for preschool mathematics: Construct validity of a new teacher interview. Journal of Research in Childhood Education, 26(3), 291-307. https://doi.org/10.1080/02568543.2012.685123

McCray, J. S., \& Chen, J. Q. (2012). Pedagogical content knowledge for preschool mathematics: Construct validity of a new teacher interview. Journal of Research in Childhood Education, 26(3), 291-307. https://doi.org/10.1080/02568543.2012.685123

Medallon, M. C. (2013). Faculty Performance as a Function of teaching Goals and Organizational Commitment. International Journal of Scientific \& Technology Research, 2(11), 66-72.

Mishra, P., \& Koehler, M. J. (2006). Technological Pedagogical Content Knowledge: A framework for teacher knowledge. Teachers College Record, 108(6), 1017-1054. https://doi.org/10.1111/j.1467-9620.2006.00684.x

Niess, M. L. (2005). Preparing teachers to teach science and mathematics with technology: Developing a technology pedagogical content knowledge. Teaching and Teacher Education, 21(5), 509-523. 
https://doi.org/10.1016/j.tate.2005.03.006

Ranjit, B. (2004). Knowledge Management Metrics. Industrial Management \& Data Systems, 104(6), 457-68. https://doi.org/10.1108/02635570410543771

Schutz, P. A., Crowder, K. C., \& White, V. E. (2001). The development of a goal to become a teacher. Journal of Educational Psychology, 93(2), 299-308. https://doi.org/10.1037/0022-0663.93.2.299

Shank, M. J. (2006). Teacher storytelling; a means for creating and learning within a collaborative space. Teaching and Teacher Education, 22(6), 711-721. https://doi.org/10.1016/j.tate.2006.03.002

Shulman, L. S. (1986). Those who understand: A conception of teacher knowledge. American Educator, 10(1), 9-15, $43-44$.

Shulman, L. S. (1987). Knowledge and teaching: Foundations of the new reform. Harvard Educational Review, 57(1), 1-22. https://doi.org/10.17763/haer.57.1.j463w79r56455411

Sibuyi, C. D. (2012). Effective Teachers Pedagogical Content Knowledge in Teaching Quadratic Functions in Mathematics (Doctoral Dissertation of Pretoria).

Skerlavaj, M., Song, J. H., \& Lee, Y. (2010). Organizational Learning Culture and Innovations in South Korean Firms. Expert Systems with Applications, 37, 6390-6403. https://doi.org/10.1016/j.eswa.2010.02.080

The College of Business and Management. (2014). Career Preparation and Internships Program "Transforming our students' Potential into Life-long Success". Lynn University.

Volujevica, A. (2012). Role of Internal and External Communication: Case of Bank Citadel (Bachelor thesis, Aarhus University).

Wu, F. (2010). The Research on University Innovative Capability Promoting Regional Innovation System. Business School, Nankai University, China.

\section{Copyrights}

Copyright for this article is retained by the author(s), with first publication rights granted to the journal.

This is an open-access article distributed under the terms and conditions of the Creative Commons Attribution license (http://creativecommons.org/licenses/by/4.0/). 